\begin{tabular}{l|l} 
Variants & $\begin{array}{l}\text { Variants } \\
\text { The Journal of the European Society for Textual } \\
\text { Scholarship }\end{array}$
\end{tabular}

12-13 | 2016

Varia

\title{
The Complete Prose of T. S. Eliot: The Critical Edition
}

\section{Matthew Creasy}

\section{OpenEdition}

\section{Journals}

Electronic version

URL: http://journals.openedition.org/variants/397

DOI: 10.4000/variants.397

ISSN: 1879-6095

\section{Publisher}

European Society for Textual Scholarship

\section{Printed version}

Date of publication: 31 December 2016

Number of pages: 260-263

ISSN: 1573-3084

\section{Electronic reference}

Matthew Creasy, «The Complete Prose of T. S. Eliot: The Critical Edition », Variants [Online], 12-13 |

2016, Online since 01 May 2017, connection on 23 September 2020. URL : http://

journals.openedition.org/variants/397 ; DOI : https://doi.org/10.4000/variants.397

This text was automatically generated on 23 September 2020.

The authors 


\title{
The Complete Prose of T. S. Eliot: The Critical Edition
}

\author{
Matthew Creasy
}

\section{REFERENCES}

The Complete Prose of T. S. Eliot: The Critical Edition. Vol. 1: Apprentice Years, 1905-1918. Eds. Jewel Spears Brooker and Ronald Schuchard. Baltimore: Johns Hopkins Press, 2014. 896 pp. ISBN 9781421406756.

The Complete Prose of T. S. Eliot: The Critical Edition. Vol. 2: The Perfect Critic, 1919-1926. Eds. Anthony Cuda and Ronald Schuchard. Baltimore: Johns Hopkins Press, 2014. 992 pp. ISBN 9781421406770.

1 As a critic, T. S. Eliot was fond of recommending that readers engage with the complete works of favoured writers. "To understand Baudelaire", he wrote in 1927, "you must read the whole of Baudelaire", repeating similar instructions from eight years earlier:

When we say that [Ben] Jonson requires study, we do not mean study of his classical scholarship or of seventeenth-century manners. We mean intelligent saturation in his work as a whole; we mean that in order to enjoy him at all, we must get to the centre of his work and his temperament, and that we must see him unbiased by time, as a contemporary. And to see him as a contemporary does not so much require the power of putting ourselves into seventeenth-century London as it requires the power of setting Jonson in our London. (II, 51)

Eliot's reference to "intelligent saturation" suggests an engagement with his material that goes beyond a conscientious critic's attempt to read as much on a given subject as possible. In this passage, it comes to connote the operation of something like the paradoxical "historical sense" he describes in "Tradition and the Individual Talent" where he urges poets to acquire "a sense of the timeless as well as the temporal and of the timeless and of the temporal together" (II,106). It becomes hard not to think of the juxtaposition in The Waste Land of older voices from literature and myth with "contemporary" scenes. 
This passage, then, exemplifies the interest of Eliot's Collected Prose as it is now being assembled in eight volumes under the editorial direction of Ronald Schuchard. Not only is he a compelling critic and thinker, but Eliot's critical views shed important light upon his practice as a poet. This is clear from the broader resonance of "saturation" across his writings. Five months before he published this account of Jonson in the Times Literary Supplement during November 1919, Eliot used the same word in the Egoist to describe the influence of Seneca upon George Chapman, citing an allusion to "the cunning axeltree" in Bussy D'Ambois as an example of "the saturation which sometimes bursts spontaneously into originality" (II, 67) - the emphasis is Eliot's. Seven years later, writing about Lancelot Andrewes, he observed: "It is only when we have saturated in ourselves in his prose, followed the movement of his thought, that we find his examination of words terminating in the ecstasy of assent" (II, 822). In these passages, "saturation" evokes a dynamic force, linked to a sense of creative transformation. In this context, Eliot's misquotation from Chapman has a rich textual history. As his editors note, the phrase should read "burning axel-tree", but was misprinted in the Mermaid edition he owned. Eliot's own saturation in this image was such that Chapman's adaptation of Seneca re-echoes in "Gerontion", "Marina" and Four Quartets. Likewise, when Eliot republished the essay on Andrewes in the collection For Lancelot Andrewes (1928), it became inseparable from his public declaration of assent there, in the announcement that he was "classicist in literature, royalist in politics and anglocatholic in religion". In each instance, "saturation" conveys the intensity of Eliot's experiences as a reader and the impact of those experiences upon his poetry, thought and belief.

4 Although only two volumes (covering his life up to 1926) have been published so far, the scope of the Complete Prose is admirably broad, offering readers the chance to begin the kind of comprehensive engagement Eliot himself favoured. Drawing heavily upon the bibliographical work of Donald Gallup it brings together for the first time a great number of essays and reviews that Eliot did not see fit to republish during his lifetime, including important works such as Eeldrop and Appleplex, the only prose fiction he published as an adult. But these volumes go beyond Gallup in tracking down unsigned or unacknowledged items and by reproducing transcriptions of previously unpublished documents, from stories written as a schoolboy to the essays on philosophy Eliot wrote during his studies at Harvard and Oxford. The editors anticipate the inclusion of two hundred items that were not listed by Gallup by the time this project is completed. This bibliographical achievement is supplemented by extensive and scrupulous annotations, as well as lucid and thoughtful introductions to each phase of Eliot's career.

The format of these volumes encourages a historically sensitive approach, carefully reproducing texts in the chronological sequence of their composition. Accordingly, his doctoral thesis on F. H. Bradley is now reproduced alongside his other early student writings, although Eliot didn't publish it until 1964. His public career as a poet and literary critic emerges here from his philosophical background, not least through the reviewing he undertook for philosophical journals, such as the International Journal of Ethics. Similarly, the Clarke lectures on metaphysical poetry Eliot gave in 1926 previously edited by Schuchard within Varieties of Metaphysical Poetry (1996) - appear here amongst his other critical writings from the 1920s. His Cambridge thoughts on Donne and Laforgue are found developing from the renewed interest in Elizabethan and Jacobean writers that Eliot took after the First World War. 
Whilst this presentation has clear benefits, other textual decisions produce more mixed results. In most cases, the editors reproduce the latest versions of essays that Eliot chose to revise for inclusion in collections such as The Sacred Wood. In the Times Literary Supplement, for example, Eliot described "the power of setting Jonson in our London" as "a more difficult triumph of divination". Although he kept these final words when he combined this article with another review from the Athenaeum to form the single essay "Ben Jonson" for The Sacred Wood (1920), Eliot cut them from the Selected Essays (1932). The latter text is given in the Complete Prose so that items such as this are reproduced in the sequence of their first publication, but derived from asynchronous textual sources.

7 Notes accompanying each essay clarify the difference between these versions, which vary in amplitude and significance. They also reproduce passages Eliot cut from articles and reviews, so it is possible to reconstruct the original versions using this apparatus. Whilst The Sacred Wood is still in print, however, the historical and bibliographical interest lies more strongly in the original periodical versions of these texts, which have until now only been available through archival research and some digital repositories. Indeed, anyone interested in The Sacred Wood will still need to consult that volume separately for a fuller sense of Eliot's intentions for the collection because its contents now are dispersed across the Collected Prose.

Whilst this editorial decision seems flawed to me, it does not detract from the overall scholarly achievement in these volumes. Perhaps more imaginative use of the edition's present digital format would have helped here (a print version is envisaged only after completion of the final volumes). Indeed, the editors announce their eventual intention to create a website of supplementary material including juvenilia, interviews, blurbs and endorsements and personal notes by Eliot. There's a purposive comprehensiveness about this project that will ensure it becomes an outstanding resource for scholars, literary historians and readers of all kinds.

\section{AUTHORS}

\section{MATTHEW CREASY}

Matthew Creasy is a Lecturer in English Literature at the Universityof Glasgow. He has published essays and articles on James Joyce and William Empson, and his edition of Arthur Symons' The Symbolist Movement in Literature was published by Carcanet-Fyfield in 2014. 